\title{
THE TRANSFORMATION OF GERMAN CONSUMER COOPERATIVES AFTER THE SECOND WORLD WAR
}

\author{
JANA STOKLASA
}

HISTORICAL COMMISSION OF LOWER SAXONY AND BREMEN

\begin{abstract}
In Germany, as in other parts of Europe, workers faced social and political challenges in the process of industrialization. Consumer cooperative societies, or coops, emerged at the end of the nineteenth century as an answer to these challenges. As self-help organizations of workers, they developed into a stable pillar of the German labor movement. In 1932 they counted four million members. After 1945, under Allied supervision, "denazified" coops helped to reconstruct Germany, which was then divided into two opposing political camps. After the war, former victims of the Nazi regime, perpetrators of Nazi crimes, and bystanders all preferred to avoid discussing the Nazi past. Reconstruction in both German states focused on rapidly restoring the war-damaged economy, while ignoring the other burdens of the Nazi past. Most of today's discussion of coops' post-war reconstruction in Germany centers on economics. Due to various historical interrelations, critical discussion of the burdensome past remains buried. In this paper, I reflect on the transformation of the consumer cooperatives during and after the Second World War, based on archival sources documenting the denazification of the Hannover Consumer Cooperative Society in the British occupation zone and the restitution of property it lost under Nazi rule. I argue that despite the nearly complete demise of German consumer cooperatives after reunification in 1990, the buried history of how they handled the Nazi past should come to light.
\end{abstract}

Keywords: Germany; consumer cooperative societies; Konsum; coop AG; restitution; Nazism; Cold War

DOI: $10.14712 / 23363231.2020 .9$

This article draws upon research conducted for my doctoral dissertation entitled "Umstrittenes Vermögen: Kalter Bürgerkrieg und Vergangenheitsblindheit in Wiedergutmachungsverfahren für nationalsozialistisches Unrecht (1948-1968)" and defended at the Institute of Didactics of Democracy, Historical Department, Leibniz University Hannover.

Jana Stoklasa, Ph.D. is a research assistant at the Historical Commission of Lower Saxony and Bremen. Address correspondence to Historische Kommission für Niedersachsen und Bremen, Am Archiv 1, D-30169 Hannover. E-mail: jana.stoklasa@gmx.net. 


\section{Introduction}

After their destruction under the Nazi regime, consumer cooperative societies did not succeed in regaining the importance they had in the time before and after the First World War. In Western as well as Eastern Germany, consumer cooperative societies had to accept bitter defeat [...]. The disaster that befell the coops proves that their legal form was not a random event. As the Equitable Pioneers of Rochdale believed, a cooperative society cannot be run as a for-profit company. ${ }^{1}$

Following their infiltration and liquidation under the Nazi regime, German consumer cooperatives were revived, only to face another transformation, this time under the political constellations of the Cold War. ${ }^{2}$ After the Second World War, the coops were taken over by the Social-Democratic Party in West Germany. In East Germany, the dogma of the planned economy determined how the coops' past was handled. However, on both sides of the ideologically divided Germany, the coops' collaboration with the Nazi regime and their intentional or unintentional support for it were one way or another left behind in history and memory.

Under the Nazi regime, property belonging to consumer cooperatives in an estimated value of 500 million Reichsmarks (RM) was gradually transferred to the Nazi machine. ${ }^{3}$ In order to preserve themselves economically, German consumer cooperative societies somehow adapted themselves to the Nazi political system and to the tasks of supplying goods to the German population and fulfilling war-related and political aims. Even though exceptional acts of resistance occurred, ${ }^{4}$ the German coops were all but eliminated or privatized by

1 Burchard Bösche and Jan-Frederik Korf, 150 Jahre Konsumgenossenschaften in Deutschland. 100 Jahre Zentralverband deutscher Konsumgenossenschaften e.V. (Hamburg: Stern'sche Druckerei, 2003), 51.

2 Brett Fairbairn, "Wiederaufbau und Untergang der Konsumgenossenschaften in der DDR und in der Bundesrepublik 1945 bis 1990," in Internationale wissenschaftliche Korrespondenz zur Geschichte der deutschen Arbeiterbewegung 34, No. 2 (June 1998): 198.

3 By the term Nazi machine, I refer to the merging of tangible assets and intangible values that occurred in a plethora of National Socialist organizations, in accord with the so-called leader principle (Führerprinzip). Along with the restitution of tangible assets after 1945, reconstruction required reaffirming the values with which the organizations had been identified before 1933 . Economic, social and political aspects were tightly interwoven in the history of the consumer cooperatives.

4 One exceptional act of resistance to the Nazis consisted of the founding of "transfer companies" (Auffanggesellschaften) as branches of the coop's source of supply, the Wholesale Company (Großeinkaufsgesellschaft, GEG) during the forced liquidation of the coops after 1936. In the Memorandum of the German Central Association of Consumer Cooperative Societies 
1941. After that, their successor organizations produced goods with the help of forced laborers. The goods they produced moreover helped sustain the concentration camps. Therefore, in the twelve years of National Socialism, German coops and their members, who had previously followed the so-called Rochdale principles $^{5}$ of worker solidarity, experienced the erosion of their high-minded intangible values by the encroachment of Nazi ideology. Furthermore, in the labor environment of the coops, perpetrating, opposing, being a bystander and benefiting were intertwined during the Nazi regime. The coops had served as a society-reforming instrument before the Second World War and moreover performed a strategic supply function during the war. To this day, the dominant narrative of the memory culture emphasizes the persecution, obstruction and intimidation ${ }^{6}$ of the coops, suggesting that during the Third Reich, the consumer cooperatives were no more than victims of Nazi Germany.

Even in recent years, the contributions of the nazified coops to the German war economy and to crimes like forced labor have barely been discussed. ${ }^{7} \mathrm{We}$ can speak here about an astonishing lack of interest in how post-war transition

(Denkschrift des Zentralverbandes deutscher Konsumgenossenschaften) of 1950, the founding of these companies was already viewed as an act of resistance to the Nazis at that time. See Reparation file, Collection Nds. 720 Hannover Acc. 2009/126 No. 882/8, Niedersächsisches Landesarchiv Hannover.

5 In 1844, 28 weavers founded one of the most well-known coops in Rochdale near Manchester in Great Britain - the Rochdale Society of Equitable Pioneers. The Rochdale Pioneers are famous for having designed practices that later became the Rochdale principles: open membership, democratic control, distribution of surplus in proportion to trade, payment of limited interest on capital, political and religious neutrality, cash trading and promotion of education. Ever since 1895, maintaining this set of principles has been a requirement for membership in the International Cooperative Alliance. To this day, the Rochdale principles are the foundation on which coops operate worldwide. Brett Fairbairn, The Meaning of Rochdale: The Rochdale Pioneers and the Co-operative Principles (Saskatchewan: Centre for the Study of Co-operatives, 1994).

6 Erwin Hasselmann, Geschichte der deutschen Konsumgenossenschaften (Frankfurt am Main: coop Verlag, 1971); Karl Ditt, "Die Konsumgenossenschaften im Dritten Reich," in Internationale Korrespondenz zur Geschichte der deutschen Arbeiterbewegung 23, No. 1 (March 1987): 82-111; Gert-Joachim Glaeßner, Arbeiterbewegung und Genossenschaft. Entstehung und Entwicklung der Konsumgenossenschaften in Deutschland am Beispiel Berlins (Göttingen: Vandenhoeck \& Ruprecht, 1989); Ulrich Kurzer, Nationalsozialismus und Konsumgenossenschaften. Gleichschaltung, Sanierung und Teilliquidation zwischen 1933 und 1936 (Pfaffenweiler: Centaurus, 1997); Hans Pohl, "Die Rekonstituierung der konsumgenossenschaftlichen Organisation nach dem Zweiten Weltkrieg" in Hans Pohl, Wirtschaft, Unternehmen, Kreditwesen, soziale Probleme. Ausgewählte Aufsät$z$ e, VSWG-Beihefte No. 178/1 (Stuttgart: Franz Steiner, 2005), 373-381; Hans Pohl, Aufstieg und Niedergang der deutschen Konsumgenossenschaften (Stuttgart: Franz Steiner, 2007).

7 Jan-Frederik Korf, Von der Konsumgenossenschaftsbewegung zum Gemeinschaftswerk der Deutschen Arbeitsfront: Zwischen Gleichschaltung, Widerstand und Anpassung an die Diktatur (Norderstedt: Books on Demand, 2008); Wilhelm Kaltenborn, Schein und Wirklichkeit. Genossenschaften und Genossenschaftsverbände. Eine kritische Auseinandersetzung (Berlin: Das neue Berlin, 2014); Mi- 
and restitution were performed and how they impacted the post-war development of the German coops, if they did at all. This lack of interest reflects how deeply repressed the contributions of German labor organizations to the Nazi regime were in the memories of the post-war organizations that succeeded them.

Coming to terms with the Nazi past of the German coops requires us to reappraise the pathways they chose during and after the Third Reich. ${ }^{8}$ This needs to happen from a perspective that questions the initial post-war narrative, which reflected the "patterns of excuse" that were typical of the post-war generation. ${ }^{9}$ Historical authenticity and conscious public acknowledgment of guilt are required for successfully dealing with the past. Therefore, I aim to encourage a historical dialogue ${ }^{10}$ on how the Nazi past of German consumer cooperatives was made "bearable."

In order to fill the gap in the literature, I aim to describe the organizational transformation of the coops in the post-war years. I regard the organizations that pursued the restitution and denazification process as transitional entities. In the first part of this paper, I address the post-war reconstruction of the coops in the British occupation zone from the late 1940s until the mid-1950s, a period which saw them denazified, but which at the same time downplayed their implication in Nazi crimes. On the macro-historical level, how was the reconstruction of the coops framed by the East German-West German duality?

In the politically divided post-Nazi Germany, the refusal to critically investigate Nazi crimes was characteristic of large parts of the population and social groups, including academia. ${ }^{11}$ For the consumer coops in both parts of Germany,

chael Prinz, "German Co-operatives: Rise and Fall 1850-1970," in A Global History of Consumer Co-operation since 1850: Movements and Businesses, ed. Mary Hilson et al. (Leiden: Brill, 2017).

8 There is a need for reappraisal of the roles of other parts of German society during the Nazi regime, as has recently been done for dentists: See "Bundespressekonferenz: Zahnärzte im Nationalsozialismus. November 28, 2019," on the homepage of the Institute of Medical History, Theory and Ethics, Uniklinik RWTH Aachen, https://www.ukaachen.de/kliniken-institute/institut-fuer-geschichte -theorie-und-ethik-der-medizin/aktuelles/news/artikel/bundespressekonferenz-zahnaerzte -im-nationalsozialismus.html.

9 Sebastian Brünger, Geschichte und Gewinn. Der Umgang deutscher Konzerne mit ihrer NS-Vergangenheit (Göttingen: Wallstein, 2017).

10 Historical dialogue and accountability are a growing field of advocacy and scholarship that encompass efforts to come to terms with the past. They are tools for achieving reconciliation and promoting democracy. This field places special emphasis on reaching new generations and considering how the meaning of the past changes with the passage of time. See "What is Historical Dialogue?" on the homepage of the Institute for the Study of Human Rights, Columbia University, www.humanrightscolumbia.ord/ahda/what-historical-dialogue.

11 The case of the sociologist Hanna Meuter, who in 1948 publicly expressed regret for the Holocaust, was something of an exception to the rule. We can say that the Nazi past was examined more 
the silence about the crimes and collaboration allowed them to claim victim status. In the Soviet occupation zone, this tendency was even greater than in the West because the coops were forcibly integrated into the planned economy. Britain was the original home of the cooperative movement and British influence was decisive in the reconstruction of the German coops in all of the Western occupation zones. Therefore, it will be useful to examine an example of a coop from the British occupation zone.

In order to frame the specific reconstruction and denazification experiences I present, in the first part of my paper I look at the economic and political adaptation and subsequent integration of the coops into the National Socialist war economy, as well as their later demise after Germany was reunified. In the light of this "special German path," 12 I argue that what I call a "missed new beginning," when the chance to confront the Nazi past was passed up, contributed to the demise of the coops at the time of reunification.

In the second part of my paper, I present my micro-historical research into the denazification of the Hannover Consumer Cooperative ${ }^{13}$ in Lower Saxony, then in the British occupation zone, and its efforts to obtain restitution of property it lost under the Nazi regime. I shed light on the Hannover coop's reconstruction and denazification, which were its main challenges in the post-war period. It is important to note here that the historical sources I used strongly reflect the self-image of the coops making claims for restitution, which saw themselves as victims of persecution by the Nazi regime. Thus, in order to avoid taking on their "victim perspective," I aim to focus on the claimants' interactions with the occupation authorities as well as their situation in society.

intensively in the humanities than, for example, in the natural and economic sciences. Breaking the silence on the complicity of individuals in Nazi crimes as well as concrete experiences of persecution started with uncomfortable questions posed by the student movements of the 1960s.

12 Drawing on the debate over the existence of a so-called "special German path" (Sonderweg), I use the term here to underline that further examination of the development of German consumer cooperatives in the twentieth century is required. Although the historians agree that there is no "standard" path of national development, because every nation develops in the pursuit of different interests, I argue that the term is helpful because it highlights the political, societal and historical (dis)continuities in the development of the German consumer cooperative movement.

13 The sources I used in my research include 95 files of the Hannover Consumer Cooperatives concerning the restitution of its retail stores in the period from 1948 to 1962. These files are archived in the Lower Saxony State Archives, division Hannover (Niedersächsisches Landesarchiv Hannover, hereinafter NLA HA), in the collection Nds. 720 Hannover Acc. 2009/126. Furthermore, I have reviewed the denazification files of former Nazi-period leaders of the Hannover coop, found in collection Nds. 171 Hann. Concerning the Hannover Coop's extensive property holdings, I have reviewed files in the Federal Archives in Koblenz (Bundesarchiv Koblenz, hereafter BArch Koblenz) in collection Z 36. 
Recognizing that the German coops nearly totally disappeared in the 1990s, my aim is to examine how the challenge of rebuilding consumer cooperatives as social and economic self-help organizations was managed locally after the Nazi period. Based on a historical study of the Hannover coop in the post-war era, I discuss how the "difficult legacy" of its Nazi past was handled. I hypothesize that critical confrontations with the "dark years" were avoided during the transformation period and that the legacy of those years still remains buried in the history of the German coops.

\section{The Role of the Nazi Past in the Nearly Complete Demise of the German Coops in the 1990s}

\section{Post-War Reconstruction and the German-German Silence}

It became evident in the mid-1950s that the transition from the Nazi era and adaptation to the rapid changes taking place in the two German post-war societies were difficult for the cooperatives. ${ }^{14}$ The aim of the Allied governments to contribute to the denazification of German society by re-establishing the consumer cooperatives obviously failed. This happened even in the British occupation zone, where the authorities were inspired by the experiences of the British cooperative movement. It was already evident by the end of 1940s that the complete denazification of West German society was neither realizable nor popular. Around ten million Germans had been members of the Nazi party, the NSDAP (Nationalsozialistische Deutsche Arbeiterpartei). Accordingly, a large part of the population was potentially affected by denazification. Furthermore, in view of the urgent need to rebuild lines of supply, the leaders of the coops were essential personnel and thus could not be ousted in the course of denazification. The failure of denazifying the coops in the Western occupation zones only seemed to be different from the outcome of the policies of resocialization applied in the Soviet zone. The former NSDAP members in East Germany were legally excluded from leading positions in the consumer cooperatives, but so were the coops' former social democratic leaders. This produced yet another injustice.

Although they remained in place in the West and were purged in the East, the coop leaders' entanglements with the Nazi regime were met with "communicative silence" in both halves of Germany. A historic opportunity to authentically reconnect with traditional values was missed. The silence had a deep impact.

${ }^{14}$ Prinz, “German Co-operatives," 257. 
After the Nazis were defeated, the cooperative concept was discredited in both the East and the West. In addition, due to Nazi persecution of the pre-war coop leadership, generational change in the leadership was interrupted, contributing to a delay in the modernization process. Bringing on new leadership was an urgent matter when the standard of living of the former coop members was rising and a revolution was taking place in consumer behavior.

The East-West division of Germany certainly influenced these developments. But did the consumer cooperatives lose their ability to contribute to social change only because of the duality of German society? In West Germany, this loss became evident after the rise of the social movements of the 1960s. Although the new movements for better environmental protection and the emancipation of women celebrated ideas of broad participation, social reform and mutual self-help that were principles of the coops, as institutions of the old, pre-war social movements the coops no longer connected people. ${ }^{15}$ Obviously, the coops' original aim of transforming society and freeing the individual from the "fetters of capitalism" had been lost in the wreckage of the war. I argue that the challenges faced by the coops require further research. This research has to draw on the post-Third Reich history of labor and the effects of Westernization and Sovietization on the denazified German labor environment. It must also take into account economic and political changes in the post-war years, like rising living standards and consumerism.

\section{Westernization vs. Sovietization}

In the Western occupation zones, the problem of handling the Nazi past was "solved" by focusing on economic priorities and buckling down to the work of material reconstruction. This "escape into building the future" was typical of the post-war years. At that time, important aspects of German guilt were met with silence. ${ }^{16}$ By the middle of the 1950 s, the post-war coops had succeeded in rebuilding their business networks. In general, this would not have been possible without the help of restitution laws issued in 1945 in the Soviet occupation zone and in 1947 by the Allied occupation authorities.

In the German Democratic Republic (GDR), there was a deep cleansing of "fascists" from the cooperatives, which were there known as Konsum (from

15 Fairbairn, "Wiederaufbau und Untergang," 198.

16 Elazar Barkan, The Guilt of Nations: Restitution and Negotiating Historical Injustices (New York: W. W. Norton, 2000), 87. 
Konsumgenossenschaft - consumer cooperative). The GDR coops experienced an ideological cleansing of "mature" social democrats and unwanted dissidents. ${ }^{17}$ Then the operations of the Konsum were dictated by the central economic plan. Consequently, when civil rights and liberties were once again restricted in communist East Germany after the catastrophe of National Socialism, there was no space for the coops to distance themselves from their past entanglement with Nazi politics or to rebuild themselves in line with their former traditions. The GDR was effectively Sovietized. Moreover, the intra-German border was the front line of the Cold War. The effect of this political constellation was dystopian for the coops on both sides of Germany. As Fairbairn has pointed out, "For one Germany, the consumer cooperatives were too capitalistic, for the other too socialist." 18 Developments in the two Germanys during the post-war era of reconstruction covered up the Nazi past like a blanket.

Before the authorities in the Western occupation zones got around to restitution, Directive 176 of the Soviet Military Administration, issued in 1945 in the Soviet zone, mandated an accelerated restitution of the property of the coops that had been transferred to private persons, institutions and suppliers after 1933. ${ }^{19}$ The importance of consumer cooperatives in the Soviet zone was greater in comparison to the Nazi era and their situation in the Federal Republic of Germany (FRG). However, the coops' commercial status did not really fit into the socialist system. They were tolerated because the economy needed them, and there was a strong motivation for ordinary citizens to join them as members. The Konsum became the second most important retailers in the GDR after the Handelsorganisation ( $\mathrm{HO}$ ), which was owned and centrally managed by the GDR state. However, the position of the coops in the GDR remained unsettled. The communists regarded them as a suitable platform for reaching beyond the workplace to influence families. At the same time, although they were fully integrated into the planned economy, they were accused of being deficient in the political work that was the duty of all organizations in the communist state. ${ }^{20}$ The

17 This happened to the consumer and building cooperative in Leipzig, when in 1949, the so-called Volkshaus group of Social Democrats was dismantled in a famous trial. Fairbairn, "Wiederaufbau und Untergang," 174.

18 Ibid, 197.

19 Volker Beuthin et al., eds. Genossenschaftsrecht der SBZ und DDR (1945-1990). SMAD-Befehle, Gesetze, Verordnungen und Musterstatuen (Göttingen: Vandenhoeck \& Ruprecht, 1997), 5-15.

${ }^{20}$ Jan Bösche, Die Konsumgenossenschaften in der Wende von 1989/90. Von der Plan-zur Marktwirtschaft am Beispiel der Genossenschaft Sachsen-Nord / Eilenburg (Norderstedt: Books on Demand, 2007), 17, https://www.kaufmann-stiftung.de/documents/Konsumgenossenschaften_Wende _von_1989_90.pdf. 
narrative of a second victimization, this time by the socialist system, overshadowed any possible critical reflections of the coops' Nazi past in such a powerful way that their activities were essentially forgotten.

The so-called Wirtschaftswunder, the reconstruction of the West German economy from nothing, was an impressive feat. ${ }^{21}$ As applied to the West German coops, the theme was what Mooser called the "organizational wonder." 22 This achievement might astonish us after we take a closer look at the economic-political subjugation of the coops under Nazism and later, their complete integration into the National Socialist war economy.

\section{Self-Preservation During the Nazi Era}

The transfer of the tangible property of the coops to the Nazi machine was a gradual process. During the economic crisis of the early 1930s, the coops were slandered by anti-cooperative propaganda. In 1933, due to the danger facing the whole economy, the Nazis' objective of a rapid and total elimination of the coops turned out to be a "utopian" dream. Beginning in 1934, the National Socialist Combat Alliance for the Commercial Middle Classes (Nationalsozialistischer Kampfbund für den gewerblichen Mittelstand - NS-Hago) ${ }^{23}$ agitated unsuccessfully with the Reich's Ministry of Economics, the Reich Trade Group, and the leadership of the German Labor Front (Deutsche Arbeitsfront, DAF) ${ }^{24}$ for immediate privatization of the coops. ${ }^{25}$ Later on, the difficulty the war economy was having in supplying the German civil population with essential goods made a rapid takeover impossible. The National Socialist persecution of the coops had to walk the line between propagandistic bombast on the one hand and avoiding totally crippling the system of supply on the other. From a political-economic perspective, the development of the cooperatives was shaped by this tension since the crisis of the 1930s.

${ }^{21}$ Fairbairn, "Wiederaufbau und Untergang," 192.

22 Josef Mooser, Arbeiterleben in Deutschland 1900-1970. Klassenlagen, Kultur und Politik (Frankfurt am Main: Suhrkamp, 1984), 204.

23 This Nazi organization represented small businessmen and was the main actor in combating the competition from the consumer cooperative societies. Ulrich Kurzer, Nationalsozialismus und Konsumgenossenschaften. Gleichschaltung, Sanierung und Teilliquidation zwischen 1933 und 1936 (Pfaffenweiler: Springer, 1997), 158-159.

24 In early 1933, this one National Socialist trade union replaced all former trade unions.

25 At the end of 1934, there were 3,281,400 coop members (compared to 3,654,402 in 1932). The coops' total revenue decreased from 1.1 billion RM in 1932 to 660.1 million RM in 1934. Erwin Hasselmann, Geschichte der deutschen Konsumgenossenschaften (Frankfurt am Main: Knapp, 1971), 472. 
In the theory of the social economy, appropriating the coops' tangible assets implied the gradual obsolescence of their intangible capital, such as the principles of solidarity and self-help. The process meant the discrediting of the entire concept of the cooperative. Around 1936, so-called transfer companies (Auffanggesellschaften) were founded as branches of the Wholesale Company (Großeinkaufsgesellschaft, GEG). ${ }^{26}$ In practice, this was an exceptional form of resistance to the forced liquidation. The new form of transfer companies allowed the former coops to continue on as self-managed local organizations until 1941. In the end, however, their remaining assets were definitively transferred to a new entity, the Gemeinschaftswerk, which was established to receive them. ${ }^{27}$

Despite Gleichschaltung, the submission of all organizations to the ideology and totalitarian control of the Nazi state, the coops served as a shelter for members of the resistance until 1936. ${ }^{28}$ Still, they were always under pressure from local Nazi leaders who pursued a mission to remove unwelcome "Marxist elements" from the consumer coop networks. However, in many cases local Nazi leaders were interested in maintaining the coops in operation for personal reasons. The Reich's Ministry of the Economy found that development unsatisfactory, which resulted in the Nazi liquidation law of $1935 .{ }^{29}$

In Hannover, the transfer company provided a solution to handle this forced liquidation. Some of the stores were sold to their former employees, whereas the

26 The Großeinkaufsgesellschaft was founded in 1894 as a manufacturing and food production coop in order to supply the individual cooperatives and support the coops' concept of social reform. As the coops' wholesaler, the GEG was nazified in 1933 and began doing business with private companies in 1935.

27 This happened according to the Nazi law Verordnung über die Anpassung der verbrauchergenossenschaftlichen Einrichtungen an die kriegswirtschaftlichen Verhältnisse [Ordinance on the Adaptation of Consumer Cooperative Institutions to War Economic Conditions] of February 18, 1941. The Gemeinschaftswerk was a company owned by the DAF that consisted of 135 wartime supply networks (Versorgungsringe). The aim of the supply networks was to establish their holding company, the Gemeinschaftswerk, as a Europe-wide consumer goods group. Jan-Frederik Korf, Von der Konsumgenossenschaftsbewegung zum Gemeinschaftswerk der Deutschen Arbeitsfront: Zwischen Gleichschaltung, Widerstand und Anpassung an die Diktatur (Norderstedt: Books on Demand, 2008), 182-186.

28 Prinz, "German Co-operatives," 252.

29 The so-called Nazi liquidation law of May 21, 1935 forced about one third of the metropolitan consumer cooperatives to liquidate themselves. These urban cooperatives presented the most potential for resistance to Nazi rule. Although the self-organized liquidations meant the destruction of a substantial part of the consumer cooperative movement, this "solution" was actually a compromise. It distracted the attention of the Nazis from the wholesaling company GEG, which was the "soul" of the consumer cooperatives. 
most prominent shops were handed over to the control of local Nazi leaders. ${ }^{30}$ This strategy for survival was retrospectively classified as an act of protest in the sense that it expected and prepared for a future after the Nazi regime. But in fact, after 1945, this expectation turned into disappointment. In the first place, after 1945 , the stores were being returned on a "volunteer" basis. This was because their privatization under the Nazis was not recognized as an act of protest nor as an expropriation of property subject to restitution. Furthermore, the Hannover case shows that the nazification of the purchasers was underestimated. Rarely was there any willingness to return the stores to the coops. The coops' strategy of resilience in the face of the Nazi regime turned out to be a disadvantage during restitution proceedings. This was due to the fact that the consumer cooperative societies did not openly oppose National Socialism, but rather chose to adapt to it, mainly for economic self-preservation. The restitution proceedings did not provoke a critical discussion of the past in post-war society. Except among the so-called "hibernators" 31 who had survived in niches during the Nazi regime, the infiltration of the coops by National Socialist ideology had resulted in lasting alienation from the principles of the consumer cooperative movement expressed by the Rochdale pioneers.

\section{A Missed Chance for a New Beginning}

A memorandum of the German Central Association of Consumer Cooperative Societies (Denkschrift des Zentralverbandes deutscher Konsumgenossenschaften) from $1950^{32}$ reflects how complex the situation was. The memo was prepared in order to illustrate Nazi persecution and substantiate the coops' right to restitution of the stores privatized by the transfer companies after 1936. It was meant to support "difficult" restitution cases in the British and U.S. occupation zones where store purchasers refused to voluntarily return their stores to the coops.

In the memorandum, the Central Association equated the Nazis' mistreatment of the consumer cooperatives with the early persecution of the Jews. The

${ }^{30}$ In Hannover, the most prominent store in the central district (Hildesheimerstrasse 7) as well as two shops in highly frequented working-class areas (Podbielskistrasse and Berkhusenstrasse) were sold to the local and regional Nazi executives of the coop, Fritz Sohns and Willy Goerres. Reparation file, Collection Nds. 720 Hannover Acc. 2009/126 No. 145 and No. 1265, NLA HA.

31 After 1945, leaders of the cooperatives often used the term hibernate to describe the survival strategy of outwardly bowing to National Socialist policy while preserving an inner distance from its ideology.

32 Reparation file, Collection Nds. 720 Hannover Acc. 2009/126 No. 882/8, NLA HA. 
post-war coop association distanced itself from the "abandon and brutality" with which "the extermination of Jews" was carried out, which "no human thought possible." 33 But they missed the occasion to reflect critically on the contribution of the consumer coops and their successors to Nazi crimes. The memorandum reproduces some of the patterns of excuse common to the post-war generation. It illustrates the societal miscommunication that was typical of the early years of the FRG. Hence, I call the memorandum a "missed chance for a new beginning."

In a more self-critical analysis, there would have been a mention of how anti-Semitism and Nazi racial ideology were put into practice by the coops. Already in 1933, the Central Association, the author of the post-war memorandum, was reporting to the Reich's Ministry of the Economy that the consumer cooperatives were "free from Jewish capital" and that only a few of their employees were of Jewish religion or origin. ${ }^{34}$ Wilhelm Kaltenborn, an author and chairman of the board of the Zentralkonsum eG, has insightfully pointed out that the current literature hardly mentions the key words "racial laws" in connection with the consumer coops. ${ }^{35}$ There was no investigation of the coops' contributions to societal crimes like the use of forced labor. Likewise, the extent to which the assets of the nazified former consumer cooperatives, like the industrial bakeries and meat packing plants, supplied the Wehrmacht and later all types of labor camps, armament manufacturers, and their SS personnel, went unstated. ${ }^{36}$ The Gemeinschaftswerk's trafficking in goods that were robbed from occupied countries was also met with silence. ${ }^{37}$ Disentangling the Gemeinschaftswerk structures from the Nazi regime was thus a complicated process that lasted until the 1970s, although its dissolution began in 1945. ${ }^{38}$

33 Reparation file, Collection Nds. 720 Hannover Acc. 2009/126 No. 882/8, 9, NLA HA.

${ }^{34}$ Korf, Von der Konsumgenossenschaftsbewegung zum Gemeinschaftswerk, 69-70.

${ }^{35}$ Kaltenborn, Schein und Wirklichkeit, 273.

36 The Gemeinschaftwerk's revenues from its large-scale business operations ranged from 95 million RM in 1942 to 159 million RM in 1944. Korf, Von der Konsumgenossenschaftsbewegung zum Gemeinschaftswerk, 230-231. In the forced labor camps, next to the "normal" rations provided by the camp, additional food items were sold to the detainees for excessive prices. The board of the Gemeinschaftswerk was very interested in this reprehensible business because it produced extremely high profits. The full scope of the business remains unknown, but the practice is substantiated by fragmental archival sources. Ibid., 235.

37 Usually, this is explained by the fact that the supply situation in Germany worsened as the war progressed. The Reich's plundering of occupied countries allowed the German population a much better standard of living than in the early post-war years. In France alone, the Germans seized goods in an estimated value of 900 billion francs. The GEG received some of those French goods. Korf, Von der Konsumgenossenschaftsbewegung zum Gemeinschaftswerk, 198-206.

38 Michael Prinz, "German Co-operatives," 254, says that the Gemeinschaftswerk was dissolved in 1945. 
After 1945, in West Germany, the authorities legally restituted property that had been taken over by the Gemeinschaftswerk, while restitution of the privatized stores remained voluntary for their owners absent a court order. ${ }^{39}$ The law considered only the confiscated properties to be NSDAP assets. ${ }^{40}$ From today's perspective, we might wonder why the Gemeinschaftswerk assets were restituted without giving consideration to how they contributed to the war economy and Nazi crimes. At the same time, the privatized stores were restored to the coops only on a voluntary basis despite the fact that their privatization was originally an act of resistance. The intangible damage done to the coops was "restored" by focusing on the tangible, rapid economic reconstruction of Germany itself. Although this boom proved to be largely an illusion, the reestablished "consumer cooperatives were given ample scope in the process of reconstruction." 41

To sum up, the Nazi past of the German consumer coops is a complex issue. Persecution, self-preserving adaptation and collaboration, acts of resistance and resilience, as well as distortion and perversion of the cooperative concept flow together here. In the divided Germany, the course of post-war transition was not much questioned. Rather, the demise of the coops in the two Germanys during the late 1980s and early 1990s allowed the German consumer coops' actions be forgotten, which helped make their Nazi past "bearable."

At this point, I reflect upon the effect of the division of Germany into two states that belonged to two different political camps and the near complete demise of the coops after reconstruction. What follows is a rough outline of the process.

In the Western part of Germany, assets with an estimated value of five billion Deutsch marks (DM) were embezzled from the coops due to a lack of supervision. ${ }^{42}$ The finale of the cooperatives' Aktiengesellschaft (coop AG) was a public scandal that led to the total collapse of the corporation. The coop AG was a German corporation into which nearly 100 West German consumer cooperatives were merged beginning in the late 1960s. In 1988, the magazine Der Spiegel uncovered how coop managers had falsified the corporation's balance sheet and enriched themselves at the expense of the coop AG members. ${ }^{43}$ By

39 That was the case in the British zone. Further study of restitution practice in the other zones is required. In Hannover the reestablished post-war coops got back $80 \%$ of the stores they had lost.

40 Prinz, "German Co-operatives," 252.

41 Ibid.

42 An estimate the former coop AG speaker, Armin Peter, made in a conversation with the author, October 28, 2016.

43 "Missmanagement bei Coop: Das fast perfekte Verbrechen," manager magazin, August 28, 2001, https://www.manager-magazin.de/unternehmen/missmanagement/a-149040.html. The scandal 
forming a group of companies around the coop AG, the managers were able to appropriate the coops' assets for themselves. Their malfeasance subsisted in the manipulation of the holding companies, stock corporations, foundations and trustees in the coops' structure until the coops' property came under their complete control. Only a few million DM were found and returned in several criminal trials. It is no wonder that after this "perfect crime" West Germany had the smallest number of coop members in the world. ${ }^{44}$ This spectacular failure ${ }^{45}$ was fatal to the reputation of the consumer cooperatives ${ }^{46}$ and is an embarrassing history. ${ }^{47}$ Somehow, the embarrassment still obscures the coops' earlier history.

During the negotiations that led to reunification, the consumer cooperatives in East Germany were somehow "forgotten" in the Unification Treaty (Einigungsvertrag) between the FRG and the GDR; soon, they were dissolved. The coops received no financial support from the state for losses incurred in the course of reunification, such as those caused by monetary reform. For the "mass organizations" of the GDR, their status as instrumentalities of the unjust GDR state may have played a role in the complete ignoring of their special economic status. Most of the organizations of the former Konsum were unable to re-establish themselves after 1990 because of their heavy indebtedness. With unclear property rights and owing many debts, the former organizations of the Konsum were neither privatized nor given any state guarantees during the post-unification transformation period. ${ }^{48}$ That was a major reason for their nearly complete ruin in the regions of Eastern Germany. ${ }^{49}$

of the West German coops and its historical context are not well explored in the literature. However, there is a fiction novel that deals with the subject, written by Armin Peter, the former speaker of the coops' AG. In his novel, Peter calls himself Pitt, whose duty it is to write the story of the coop scandal. Armin Peter, Gemeinwirtschaft. Der Roman vom Soll und Ist (Norderstedt: Books on Demand, 2014).

${ }^{44}$ Fairbairn, "Wiederaufbau und Untergang," 195-196.

45 The coop eG (eingetragene Genossenschaft - registered cooperative society) in Schleswig-Holstein is today the last remnant of the consumer cooperatives in the former West Germany. It was not merged into the coop AG, which was based in Frankfurt. Supermarkets that belonged to some former West German consumer cooperatives (e.g, those in Minden and Göppingen) are now run by the EDEKA supermarket chain.

46 Prinz, "German Co-operatives," 255.

47 "Embarrassing history" is the expression used by experts on German cooperative history during the 11th Annual Congress on the Formation and the Doom of the Coop AG, see https://www .zdk-hamburg.de/blog/2016/08/tagung-zur-genossenschaftsgeschichte-entstehung-und -untergang-der-coop-ag/.

48 Fairbairn, "Wiederaufbau und Untergang," 197.

49 Thirteen of the former 198 consumer cooperatives in the German Democratic Republic (GDR) are still in existence today on the regional level. Ten of them are members of Zentralkonsum eG in Berlin, https://www.zentralkonsum.de/. 
The demise of the East German coops closely followed the coop AG scandal in West Germany. Nevertheless, after the reunification of Germany, there were more coops left in the East than in the West. ${ }^{50}$ No resurrection of the coops in one unified organizational structure took place in Germany as a whole after 1990. The possible reasons for the coops' nearly complete extinction in West Germany include the changed economic and political environment in the post-war society. Above all, the coops and their management had abandoned their idealistic principles under Nazi rule. They were never able to recoup those ideals and distinguish themselves ethically from any other type of commercial entity. This failure contributed to the more or less complete demise of the German consumer cooperatives, both East and West. ${ }^{51}$

The pressure of competition, the rise of mass production, and advances in technology helped to raise the living standard of workers in Germany after the Second World War. The commercial revolution that followed the war required the coops to rebuild themselves organizationally. ${ }^{52}$ The former neighborhood coop stores started to be replaced by large self-service supermarkets at the beginning of the 1950s. The trend to large retail chains represented one of the biggest challenges for the coops. Numerous attempts to centralize their structure failed. The coops had to accept that they were no longer leading lights in marketing development. ${ }^{53}$

The debate over how best to reform the coops lasted for over a decade. The decision to transfer their assets into an ordinary stock company was finally made in 1968. For consumers, it was supposedly the "spirit of the business" and not the legal form that was decisive in their choice of where to shop. ${ }^{54}$ But the coops' somewhat romanticized self-image was not enough to overcome the difficulties raised by challenging times.

50 There were 67 consumer cooperatives in Germany in 1993: 28 in the West (with 600.000 members) and 39 in the East (with two million members). Fairbairn, Wiederaufbau und Untergang, 196.

51 Fairbairn, "Wiederaufbau und Untergang," 173.

52 Ibid, 193.

53 Prinz, "German Co-operatives," 255.

${ }^{54}$ Bösche and Korf, 150 Jahre Konsumgenossenschaften, 39-40. 


\section{Challenging Times: The Post-war "Resurrection" of the Consumer Coop in Hannover}

\section{The Restitution Challenge}

In Hannover, similar to other German cities in the post-war period, some of the owners who had taken over the coop stores maintained that the "consumer cooperatives were liquidated for economic and business management reasons, without any apparent relation to political causes." 55 After the war, these owners of the former coop stores denied the right of the Hannover coop to restitution. They refused to return the stores they had purchased when the coops were forcibly liquidated between 1936 and 1941. Due to their intransigence and the fact that they held on to their Nazi views, the attorneys for the Hannover coop frequently referred to them as the "dregs" (Bodensatz). ${ }^{56}$

The Hannover coop lost about 20 percent of 95 restitution cases that were brought because of the unwillingness of the "dregs" to return assets to the organization. The store owners' National Socialist views were evident in the argumentation of their attorneys. After 1945, in Hannover, attorney and notary Dr. Walter Gröpke represented the interests of at least twelve opponents of the restitution of particular property to the consumer coop. Gröpke had actively denounced the coops in the Nazi period, when the regime's propaganda was defaming them as well. This was especially true during the 1930s economic crisis, when the Nazis stoked fears that led to a "run" on savers' deposits held in the coops. The run was a panic when savers withdrew their deposits from their accounts at the Hannover coop en masse. Gröpke claimed that at least 100 lawsuits were brought against the coop organization at that time. It was alleged that the coop organization had only itself to blame for its lack of liquidity. The very concept of the cooperative was effectively disgraced. This accusation was still part of the argumentation used by the "dregs" in the late 1940s to resist restitution in favor of the coops. ${ }^{57}$

Furthermore, in October 1945 the district court of Hannover reopened the liquidation proceeding that was closed in 1941 when the Hannover coop's remaining assets were transferred to the Gemeinschaftswerk and it was erased from the register of cooperatives. ${ }^{58}$ In the reopened liquidation proceeding,

55 Reparation file, Collection Nds. 720 Hannover Acc. 2009/126 No. 882/8, 2, NLA HA.

56 Reparation file, Collection Nds. 720 Hannover Acc. 2009/126 No. 1960, NLA HA.

57 Reparation file, Collection Nds. 720 Hannover Acc. 2009/126 No. 807, 14-15, NLA HA.

58 Reparation file, Collection Nds. 720 Hannover Acc. 2009/126 No. 882/5, 659-665, No. 882/1, 148, and No. 882/4, 493-494, NLA HA. There is no evidence showing when the reopened liquidation 
claims were filed demanding that the re-established coop repay loans made to it in pre-war times. However, the Allied authorities' legislation that provided the legal basis for re-establishing the coop ruled out those claims. ${ }^{59}$

Nevertheless, despite the occupation authorities' legislation, the liquidation proceeding was reopened in Hannover. Its reopening provided a new opportunity to defame the coops, as well as to argue against the coops' right to restitution of their former property. A Hetzschrift, a long inflammatory letter, was written anonymously and forwarded to the restitution authorities. ${ }^{60}$ The attempts to reanimate the anti-consumer cooperative propaganda of the Nazi years provides evidence of how challenging it was to re-establish the coops in the first post-war years, given the continuing strength of Nazi views.

In 1948, the British occupation government passed a law acknowledging that the Hannover coop was an organization that had been politically persecuted under National Socialism. Despite this legislation, the local restitution authorities in Hannover commissioned expert testimony about the economic situation of the coop before it was liquidated by the Nazis. Relying on arguments similar to those put forward in the "dregs" lawsuits, the local authorities refused to recognize the coop's right to restitution. Despite the fact that there were both economic and political motives for the Nazis' liquidation of the coops, the coops' post-war opponents' attempts to focus solely on the economic level kept the prewar anti-cooperative propaganda alive.

In view of the urgent need to avoid a post-war breakdown of society, the restitution of large assets like the bakery and the meat plant in Hannover was turned over to a Cooperative Societies Commission (Konsumvereinsausschuss, KVA). According to the British military government's Order No. 149 issued in May 1948, the Commission was established to clarify the coops' legal relationships and approve re-forming them. ${ }^{61}$ Under the supervision of the British military government, the coops were re-established from the ground up as "free" initiatives. The KVA in fact gave the coops privileged access to restitution in the British zone of occupation. In the case of the Hannover meat plant, when the Supreme Finance Department (Oberfinanzdirektion) ${ }^{62}$ refused to allow its restitution to

proceeding was closed. However, it was used in other restitution proceedings as an argument against the rights of the re-established coop organization.

59 Order No. 39 of the British military government, issued in July 1946, repealed the Nazi laws enacted from 1935 to 1941.

${ }^{60}$ Reparation file, Collection Nds. 720 Hannover Acc. 2009/126 No. 882/9, NLA HA.

${ }^{61}$ Walter Petrich, Kommentar zum Rückerstattungs-Gesetz: Militärgesetz Nr. 59 vom 12. Mai 1949 (Britische Zone) (Paderborn: Mohr Siebeck, 1949), 95-98.

62 The Supreme Finance Department in Hannover was an intermediate tax authority of the FRG. 
the Hannover coop, it was the KVA that helped obtain an admission of guilt from the Supreme Finance Department and supported the Hannover coop's right to restitution. ${ }^{63}$ The process took five years and without the involvement of the British authorities there was little if any chance that the parties could have come to an agreement. ${ }^{64}$ In 1957, British policy was incorporated in West Germany's Federal Restitution Law (Bundesrückerstattungsgesetz), ${ }^{65}$ which legally recognized the coops as organizations that had been persecuted by the Nazis.

On the basis of the above-mentioned legislation, about 80 percent of the privatized Hannover coop stores were restituted to the Hannover coop by the mid1950s. Usually, the transfers of ownership relied on mutual agreements between the purchasers and the reestablished Hannover coop. The coop got the privatized store back by repaying the purchase price in Deutsch marks at a one-for-one rate of exchange for Reichsmarks. ${ }^{66}$ In the frame of these mutual agreements, the Hannover coop benefited from the shop-owners' uncertainty about the legal situation concerning the restitution of privatized coop stores. The Hannover coop claimed the establishment of the KVA in 1948 was an acknowledgment of its rights. It did not mention the legal difficulties concerning the restitution of the privatized stores to the Nazi-era purchasers.

The Central Association represented the consumer coops in the restitution proceedings. It referred to the co-optation of the coops by National Socialism as "denaturing" (Denaturierung) ${ }^{67}$ As already pointed out, the Central Association's memorandum on the coops' persecution by the Nazis missed its chance to critically address post-war guilt and deal with what "denaturing" had actually signified in practice. Consequently, in Hannover - as in other German cities the coop's industrial bakery's supplying of baked goods to the Bergen-Belsen

63 Reparation file, Collection Nds. 720 Hann. Acc. 2009/126 No. 882/5, 580-594, NLA HA.

${ }^{64}$ The meat plant had operated for only two years when it was closed in 1932. It was exploited in the anti-cooperative turmoil during the economic crisis. In 1938, it was sold to the Wehrmacht. Part of it was used by the Continental AG tire company for storage purposes. In 1955, the Supreme Finance Department in Hannover, as a legal successor of the Third Reich tax authorities, paid the Consumer Cooperative Society of Hannover 500,000 DM. Reparation file, Collection Z 36 III AZ 94/48 F, BArch Koblenz.

${ }^{65}$ Bundesgesetz zur Regelung der rückerstattungsrechtlichen Geldverbindlichkeiten des Deutschen Reichs und gleichgestellter Rechtsträger (Bundesrückerstattungsgesetz, BRüG), http://www .gesetze-im-internet.de/br_g/__11.html.

${ }^{66}$ In most cases, the pre-war purchasers did not acquire the coops' real estate. Usually they bought the right to occupy it as a tenant and the store fixtures and furniture.

67 This term was used in the memorandum from 1950. Reparation file, Collection Nds. 720 Hannover Acc. 2009/126 No. 882/8, NLA HA. 
concentration camp, ${ }^{68}$ as well as its utilization of around 30 forced laborers, ${ }^{69}$ was simply not talked about.

It is noteworthy that the last director of the Hannover supply network, Werner Roggenbach, escaped from Hannover four days before the British occupied the bakery. In his later denazification proceeding, he argued that he had to flee because the forced laborers would have killed him after the British arrived. Former employees described Roggenbach as a "sadist" and "Nazi fanatic" who forced employees to give the Hitler salute. During air raids he chased the forced laborers, even pregnant women, out of the bunker in the bakery at gunpoint. ${ }^{70}$ Nevertheless, in 1946 the post-war GEG certified that Roggenbach had "brought the organization well through the perils of the time."71

\section{Denazification versus Renazification}

Up to the year 1955, the Cooperative Societies Commission (KVA) was the trustee for the assets of the consumer cooperative in the British occupation zone that were subject to restitution. It oversaw restitution only for collectives, not for individuals. In practice, the commission had exclusive jurisdiction over the assets and its decisions could not be appealed. ${ }^{72}$ The commission members were its British chairman, D. H. C. Willers (in Hamburg), and four German coop members: Peter Schlack (Cologne), August Ellenbeck (Essen), Hans Schwartz (Kiel), and Carl Schumacher (Hamburg). ${ }^{73}$

A closer look at Schumacher's biography reveals how post-war reconstruction of the coops proceeded in practice, with the service of former Nazi collaborators like Schumacher. In 1929, Schumacher was already active in different positions in the consumer cooperative movement. During the Nazi era, he was an NSDAP member and an authorized special representative of the Gemeinschaftswerk. It was at that time that Schumacher's career really took off. He profited from Nazi rule and assisted the regime. In 1944, Schumacher was responsible for the dismissal of Jewish coop employees. ${ }^{74}$

68 Steffen Meyer, Ein Kriegsgefangenen- und Konzentrationslager in seinem Umfeld: Bergen-Belsen von "außen" und "innen" 1941-1950 (Stuttgart: ibidem, 2003), 57.

${ }^{69}$ Denazification file, Collection Nds. 171 Hann. No. 38190, NLA HA.

70 Ibid.

71 Ibid.

72 Reparation file, Collection Z 36 finding aid, 2, BArch Koblenz.

73 Reparation file, Collection Z 36 finding aid, 45-50, BArch Koblenz.

74 Korf, Von der Konsumgenossenschaftsbewegung zum Gemeinschaftswerk, 270. 
During the rebuilding period after the war, Schumacher proved that he had changed his political spots by helping to oust former Nazi representatives from their positions in the coops. He was able to do this because he possessed the organization's personnel files, which he had maintained himself during the $1940 \mathrm{~s}^{75} \mathrm{In}$ the first years of reconstruction, a GEG commission, of which Schumacher was a member, decided whether to dismiss former Nazis from employment. ${ }^{76}$ From today's perspective, his participation on the commission seems inappropriate, but in the post-war period it was not uncommon. At the time, there was another perception of citizens' cooperation with the Nazis. Any sensitivity to continuing, personally held Nazi views was superseded by the urgent need to restore the supply situation. Thus, because Schumacher was active in rebuilding a democratic post-war state, he was able to become a member of the KVA board in 1948 and to serve as its chairman and a member of the GEG board of directors from 1954 to $1957 .{ }^{77}$ His earnings in the post-war reconstruction are known to have been considerable. $^{78}$

In Hannover, Schumacher's post-war activity was manifested in the restitution case of a textile store formerly owned by the consumer coop. During the forced liquidation of the coops in 1940, the store, in a building in the middle of Hannover's old town, was bought by the regional Evangelical Lutheran Church. ${ }^{79}$ Schumacher himself chaired meetings where the representatives of the regional church office (Landeskirchenamt, LKA) assured the commission of their willingness to arrive at an agreement and compensate the coop in cash, because the former textile store building had become the LKA's post-war headquarters. But when the time came to act in 1949, the representatives of the LKA at first refused to agree to any restitution. Then, after they signed an agreement in 1951, they dug in their heels and waited for resolution of the afore-mentioned "dregs" restitution cases. The Central Association's memorandum documenting the coop's persecution by the Nazis was provided to the LKA. ${ }^{80}$ The Hannover

75 The files were in 37 folders that concerned the managing directors of the supply rings. Korf, Von der Konsumgenossenschaftsbewegung zum Gemeinschaftswerk, 8.

76 In 1945, 68 of the former 258 Nazi directors were approved for continued employment. Ibid, 267.

77 Ibid.

78 Carl Schumacher (20.8.1903-10.7.1993), Zeitschrift für das gesamte Genossenschaftswesen 44, No. 1 (2017): 57-58, doi: 10.1515/zfgg-1994-0109.

79 Although church institutions were not allowed to purchase real estate during the Nazi era, in this case an exception was made, probably because there were no other interested buyers.

${ }^{80}$ Reparation file, Collection B1A No. 77, Landeskirchliches Archiv Hannover. Although the LKA was the opponent to the restitution of the property and not the claimant, the file on the proceedings is stored in the LKA's archive and not in the Regional Archive of Lower Saxony as is usual. 
Figure 1: Advertisement of the Consumer Cooperative Society Hannover, 1930.

Source: ver.di Landesbezirk Niedersachsen Bremen/co opGeschichtsgruppe Hannover, ed., Bildgeschichte der Konsum-Genossenschaften in Niedersachsen: co op - ein Stueck Wirtschafts- und Sozialgeschichte 1867-1994, Archiv mit 1250 Dokumenten

(Hannover 2008), CD-ROM, chapter $8.2,61$.

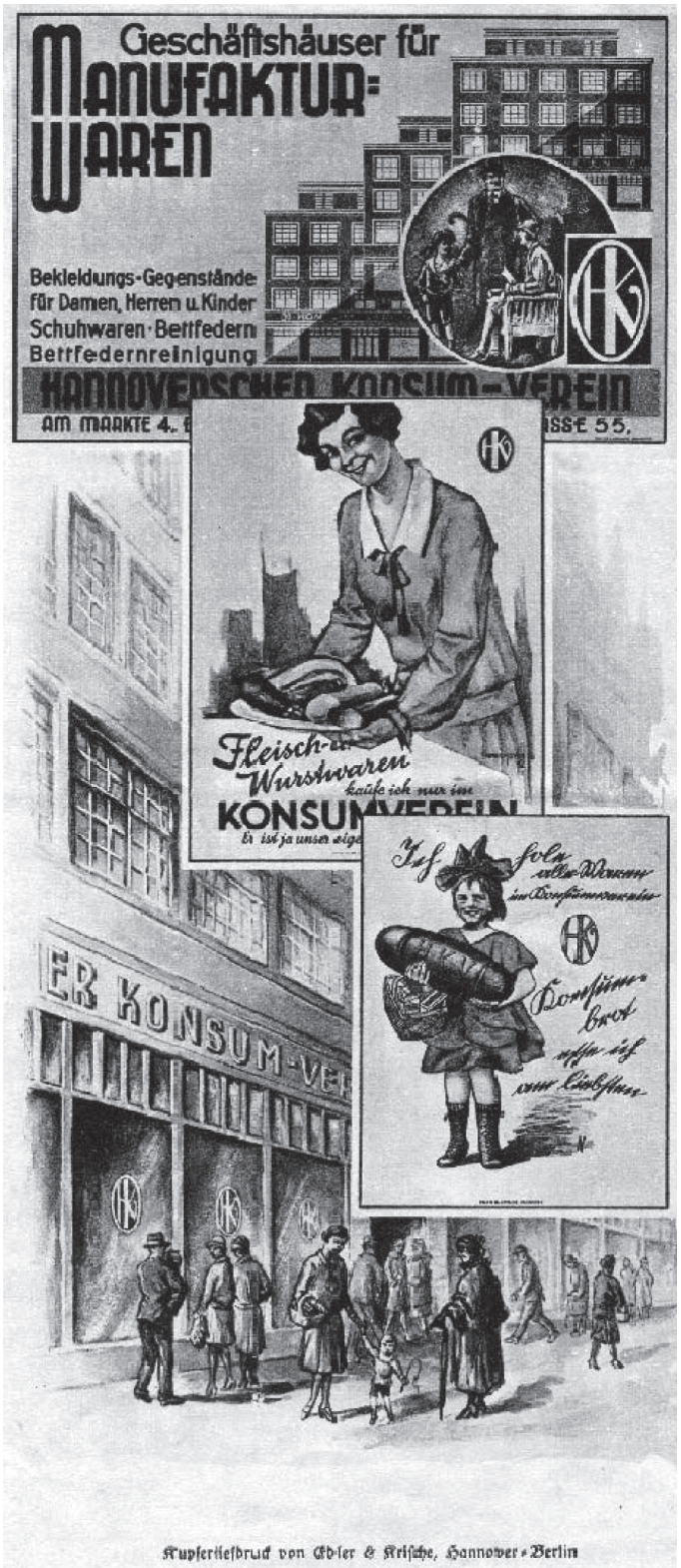


coop was interested in a "conciliatory settlement with the church." For its part, the LKA wanted to find documents that would show the economic situation of the Hannover coop before its liquidation by the Nazis. It hoped the documents would prove that the liquidation happened for economic, not political reasons. As it turned out, the LKA paid the full value of the coop's building only in $1955 .{ }^{81}$ Even now, the keepers of the culture of memory in Hannover have difficulty dealing with the building's (today known as the Hanns-Lillje-Haus) complex history. ${ }^{82}$

The case of Karl Schäfer is another interesting example of how challenging the reconstruction of the Hannover coop and denazification were. Schäfer came to Hannover in 1940 and took over the management of the Hannover transfer company, Gesellschaft für Haushaltsbedarf, from his predecessor Willy Görres. Then, in 1941, as the transition was finally made to the Gemeinschaftswerk, Schäfer became the deputy director of the Hannover supply network. When the director, Roggenbach, fled Hannover to escape imprisonment by the British military, Schäfer became the supply network's director. ${ }^{83}$

After May 1945 there was an urgent need to restore a functioning system for supplying goods to the population. For that reason, farmers and others who were needed to work in that system and the reorganization of the supply networks ${ }^{84}$ were generally exempted from the denazification process. Schäfer was one of those people. He was also active as a member of the advisory council of the Economic Committee (Wirtschaftsrat ${ }^{85}$ ) in Lower Saxony.

Willi Nippe was the first director who managed the reconstituted post-war Hannover coop, until March 1948. ${ }^{86}$ After that, Schäfer took over the organization, once it had been legally recognized by the KVA. But as a leader of the organization under the Nazis, Schäfer was under huge pressure from the former Hannover coop representatives who had returned to their positions and, one

${ }^{81}$ It is noteworthy that the LKA paid 115,000 RM for the building, which had an estimated value of around 373,000 RM. The LKA ended up paying the Hannover coop 40,000 DM in compensation, in five installments.

82 Today's officials of the LKA responded to a recent request for information by the author by saying that they will "wait for [me] to publish on the past of the building." Representatives of the Department of Municipal Memory Culture (Städtische Erinnerungskultur) of the City of Hannover were also hesitant to respond to the author's requests.

83 Denazification file, Collection Nds. 171 Hann. No. 48691, NLA HA.

${ }^{84}$ Reparation file, Collection Nds. 720 Hann. Acc. 2009/126 No. 145, No. 767, 5 and No. 1989, 9, NLA HA. It remains unknown when exactly the dissolution of the supply networks was complete.

85 The Economic Committee administered the re-organization of economic life in the Allied occupation zones of post-war Germany and later of the states of the Federal Republic of Germany.

86 Reparation file, Collection Nds. 720 Hann. Acc. 2009/126 No. 807, 14-15, NLA. 
way or another, had opposed National Socialism. The post-war coop representatives sought Schäfer's removal and insisted he be investigated for his ties to the Nazis. Although Schäfer was exempt from the denazification law because of his strategic position in food distribution, a denazification investigation was opened anyway and Schäfer was screened. The highly controversial proceeding was conducted by officials of the local Hannover denazification committee, which was already made aware that Schäfer was exempt from the denazification process in 1946. His case reveals that there was a bitter fight going on in Hannover concerning the employment of a Nazi leader like Schäfer in the post-war reconstruction of the coop.

Denazification escalated into a criminal complaint against Schäfer for insulting Robert Wolf, the chairman of the local denazification committee. On November 25, 1947, an article on the case of Schäfer vs. Hannover Coop appeared in the local newspaper, Hannoversche Allgemeine Zeitung, under the title "The End of a Rumor." The newspaper described Schäfer's political attitudes as "irreproachable." A few days later, after intervention by the Hannover coop, the newspaper "corrected" this statement because Schäfer's denazification process was still open..$^{87}$

The rebuilders of the Hannover coop regarded Schäfer as "unacceptable in a leading position." Schäfer however fought back vigorously. He maintained that he had not been a member of the NSDAP. He said he had only pretended to be a Nazi party member and that he had in fact been persecuted by the Nazis before he came to Hannover in 1940. Among other evidence, he submitted certificates from four former forced laborers and 109 affidavits from former supply network employees to the denazification board. By the time of Schäfer's proceeding, the practice of submitting Persilscheine (a certificate given the nickname of Persil, a laundry detergent) was common. It reflected solidarity among former Nazis and their fears of losing their employment. Moreover, Schäfer did not hesitate to intimidate witnesses and even members of the denazification board themselves. A poster from the notice board of the Hannover supply network that was sent to the British military government as evidence of Schäfer's Nazi Party membership disappeared. His denazification proceeding ended after a four-hour hearing and the case was closed in $1948 .{ }^{88}$

Schäfer's indispensability to post-war supply of goods was not mentioned at all in his file as a reason for freeing him from responsibility for his Nazi past.

87 Denazification file, Collection Nds. 171 Hann. No. 48691, NLA.

88 Ibid. 
Nor were the resistance to the nazification of the coops by their officers who after the war opposed Schäfer's rehabilitation, and the coops' integration into the Nazi war machine, much discussed. Nevertheless, the vehement stance of his opponents led to Schäfer's removal from the advisory council of the Economic Committee in Lower Saxony. However, Schäfer remained in his position as general manager and trustee of the rebuilt post-war Hannover coop until an unknown date. ${ }^{89}$

Schäfer's reappointment to head the Hannover coop in spite of the "massive tensions" between him and the "old cooperative leaders" was enforced by the British military government because Schäfer was the only remaining supply network leader. Furthermore, he claimed he had been an opponent of the Nazis. In the years after his reappointment, Schäfer used his position without scruple and did not hesitate to exert massive pressure on the denazification institutions, up to the level of Lower Saxony's State Commissioner for Denazification. His case shows what a farce denazification actually was. Its outcome suggests that at the local level, under the noses of the British and their allies, denazification actually meant renazification.

\section{Conclusion}

One of the fundamental functions of the post-war consumer cooperatives on both sides of the Iron Curtain in Germany was to distribute food at a time of social distress. Reconstruction of the coops proceeded in line with the Allies' goal of dismantling the nazified labor milieu. In the first part, I have shown that rebuilding and "democratizing" post-Third Reich society involved the "Westernizing" and "Sovietizing" of the two Germanys' consumer coop networks. The micro-historical analysis of the Hannover coop case in the second part shows that even though the coops' organizational principles like mutual self-help were given little respect under National Socialism, there was huge motivation to improve the supply situation from the late 1940s to the mid-1950s with the help of former Nazi era coop leaders.

As we consider how the post-war transformation went forward, it is important to note that improvement of the supply chain required rapid restitution of tangible assets to the coops. This occurred first in the GDR, where a "policy of forgetting" was part of the transition from one unjust regime into another. In the Western occupation zones, the problem of the Nazi past was "solved" by

89 Ibid. 
focusing on building the future and remaining silent about the crimes of Nazi rule. That silence was first questioned in social movements of the 1960s, but the coops still avoided discussion of their role in Nazi crimes.

I have shown that the reconstruction of German consumer cooperatives in the post-war period was characterized by a contradiction that was difficult to grasp and difficult to talk about. In the West, restitution of the coops' property was promoted by the Allies and this restitution was conditioned on avoiding any critical questioning of the coops' policy of self-preservation during the Nazi era. Here, also in view of the political reality of the Cold War, responsibility for the Nazi past was downplayed by an overemphasis on the coops' persecution. ${ }^{90}$ The typical excuse patterns of the post-war generation appeared in the way the coops dealt with their post-war challenges. This mode of dealing with the Nazi past is still deeply rooted in the history of the German coops.

For now, it remains an open question requiring further research how successful the transition of the coops was under circumstances where democracy was imposed on the FRG "from outside" and nazified structures were only gradually dismantled. My research into the Hannover case has illustrated the conditions and societal setting in which the rebuilding of the coops took place.

The German consumer coops did not survive for long after the reunification in 1990. As a result of these challenging historical interrelations, the "difficult legacy" of the German coops resulted in what I diplomatically call a self-romanticized memory culture.

The discussion of how the Nazi past was handled during post-war reconstruction in Hannover reveals that the Allies acted rather diligently in the British zone as they supervised the self-initiated rebuilding of the consumer coops. The British military government's restitution legislation was implemented in the late 1940s to facilitate reconstruction, at the same time as the supply networks were gradually dissolving. I have shown that as the coops were restarted, there were sharp confrontations at the local level, as former adversaries had to cooperate with each other under the supervision of the British restitution authorities. The Hannover example and the so-called "dregs" cases highlight how those who had resisted Nazi ideology clashed with those who still held Nazi views, even into the 1960s. The persistence of this conflict led to the loss of around 20 percent of the former Hannover coop stores. Further micro-historical studies of restitution and denazification in all the occupation zones would yield interesting results and comparisons.

${ }_{90}$ Fairbairn, "Wiederaufbau und Untergang," 186. 
As I have demonstrated with the Hannover example, intangible damages like the damage to the reputation of the Consumer Cooperative "brand" were not a subject of restitution claims, nor were they even discussed at all. Under the pressure of the urgent need to dissolve the Nazi machine and reconstruct the economic basis of German society, attempts at denazification went hand in hand with a willingness to overlook Nazi collaboration. ${ }^{91}$ Likewise, complex acts of resilience, like the establishment of the transfer companies, were minimized in the restitution proceedings or even turned into a disadvantage. This ambivalence reflects the view of many Germans who survived the war and who still considered anti-Nazi resistance during the Third Reich to be high treason (Hochverrat). ${ }^{92}$ Perpetrators and bystanders remained silent about their personal complicity since a critical examination and collective honoring of the resistance to the Nazis still required more temporal and emotional distance. The German consumer cooperatives also avoided introspection. Their complicity was further obscured by the coops' nearly complete demise in the 1980s and 1990s. It would not be a surprise if further studies reveal that the policy of forgetting affected the usefulness of German consumer cooperatives as an alternative economic model.

${ }^{91}$ Documents on the use of forced labor in the 135 supply networks and the factories of the Gemeinschaftswerk are scarce. In 1942 there were 2,300 forced laborers and 2,522 in 1943. No numbers are available for 1944 and 1945. The correspondence files of the post-war GEG indicate that the use of forced labor was an accepted part of the daily life of the consumer cooperatives. Korf, Von der Konsumgenossenschaftsbewegung zum Gemeinschaftswerk, 246-248.

92 This was the case until the mid-1950s for the von Stauffenberg assassination attempt on Hitler of July 20, 1944. 